See discussions, stats, and author profiles for this publication at: https://www.researchgate.net/publication/27268951

\title{
Constituent order and grammatical relations in Ewe in typological perspective
}

Article · January 2002

DOI: $10.1075 /$ cagral.4.13ame $\cdot$ Source: OAI

CITATION

1

1 author:

Felix K. Ameka

Leiden University

54 PUBLICATIONS 673 CITATIONS

SEE PROFILE
READS

205

Some of the authors of this publication are also working on these related projects:

Verb Constructions and verb semantics View project

Ghana-Togo Mountain Languages: their linguistic and cultural heritage View project 


\section{Constituent order and grammatical relations in Ewe in typological perspective*}

Felix K. Ameka

Leiden University

\section{Introduction}

The universality of grammatical relations has remained a puzzle in linguistic theory and typology (see e.g. Keenan 1976; Foley and Van Valin 1984; Andrews 1985; Dixon 1994; Palmer 1994; Dryer 1997; Van Valin and La Polla 1997). But for any generalisations to be made we need detailed studies of individual languages. As Givón (1997:28) laments: "Full documentation of formal subject and object properties in all languages is not yet available. Most conspicuously missing is fuller documentation of behaviour-and-control properties". This statement is cast against the background of the properties proposed by Keenan (1976) as universal properties for the Subject grammatical relation.

In this chapter I want to suggest that attention should be paid to the linguistic type characterisation of languages in the discussion of their grammatical marking of the central arguments in a clause. I want to demonstrate this perspective through a detailed description of the major grammatical relations in Ewe, a Kwa language of West Africa. I will show that some of the proposed subject properties, for instance, are irrelevant for Ewe precisely because of its typological structure. Furthermore, Ewe possesses a cluster of typological properties each of which has ramifications for grammatical relations. To set the scene for the rest of the discussion, these typological properties and their consequences are discussed first.

Morphologically, Ewe is an isolating language with agglutinative features. It is a language in which intra-clausal grammatical functions are defined primarily by constituent order. Languages vary in the way core syntactic arguments are marked. Some languages like Ewe employ constituent order, others use cases, particles or adpositions. Dixon (1994:49-50) proposes that 
for languages in which constituent order is the critical indicator of syntactic functions "we could suggest that a combination SV/AVO or VS/OVA would be an indicator of accusativity, and SV/OVA, VS/AVO of ergativity. Note that this sort of categorisation would not be easy for verb final languages". ${ }^{1}$ He adds "In fact I know of no language of [that] type [...] that has an ergative pattern, SV/OVA or VS/AVO" (Dixon 1994:50). An implication that can be drawn from Dixon's claim is that if a language uses constituent order to code clause level grammatical functions it will not have an ergative pattern. It is only full documentation of the mechanisms that will allow us to verify such an implication.

In addition, it seems that some coding properties in those languages that use constituent order follow from their language type to some extent. Thus even though English and Ewe may be said to be constituent order languages, English makes use of a residual agreement marking on the verb, being relatively an inflecting language. Ewe does not have any such feature. Both languages manifest contrasts in the forms of pronouns along subject vs. nonsubject lines (see below for Ewe).

Ewe is also a verb serialising language. In a serial verb construction, each verb in the series has the same subject, which is overtly expressed only with the first verb. It has been observed that some of the behavioural properties suggested by Keenan such as Equi NP and zero anaphora do not apply to some serialising languages because they lack embedded complements (Givón 1997:27). It is not entirely clear to me that this property should be linked to the serialisation parameter, so to speak. The problem may lie elsewhere. It is true that Ewe does not have sentential complements in which an argument can be omitted. However, as I will point out immediately below, there is a constraint in the language which demands the obligatory expression of arguments independently of serial verb constructions texts. However, I will also demonstrate in the course of the chapter that with certain clause combinations a nonsubject argument may be the target for omission but never the subject, even though any argument in the first clause may be the controller of such omission. Thus we need to know more about the expression and behaviour of grammatical functions in serial structures in such a language type before a conclusive decision can be reached on the matter.

Moreover, Ewe is a hypertransitive language. Many states of affairs which are viewed as involving more than one participant are coded in transitive clauses. Ewe has no verbs equivalent to some of the so-called canonical intransitive verbs such as 'run', 'jump' or 'swim' (cf Dixon 1994:124). The 
equivalents of these are expressed by transitive or two-place constructions and the verbs involved in such constructions must obligatorily take two arguments (cf. Clements 1972; Ameka 1994; Essegbey 1999, 2000). For example,

(1) Kofí fú tsi

K. move limbs in a medium water

'Kofi swam.'

Nor do the intransitive verbs in Ewe fall into the unergative and unaccusative classes (see Essegbey 1999) which are presumed to be universal in many theories (cf. Levin and Rappaport 1995). Furthermore, both arguments in a simple transitive clause have to be expressed. Thus unlike its closely related neighbour, Akan, Ewe does not have null objects in simple clauses (cf. Saah 1992 and Osam 1996, 1997 on Akan). In serial structures, however, the subject is expressed only once and any shared object is also expressed only once. In compound clauses, on the other hand, the subject is always obligatorily expressed while the second occurrence of a non-subject coreferential NP may be the target for ellipsis.

Given that Ewe has these properties which pose a challenge to the identification of argument coding patterns, the question has to be raised whether there are language internal features that consistently converge to identify some such patterns. The purpose of this chapter is to explore this question and show that there are language internal properties that can be used to identify the grammatical relations of subject, object, and second object.

The plan of the chapter is as follows. First, using the argument structure constructions described by Essegbey (1999) as the starting point, I identify the arguments that align together across the constructions (Section 2). I then explore in Section 3 the expression of the relations with these argument positions across agnate or related constructions (cf. Davidse 1997). The modes of realisation of the arguments that function as Subject and Object in serial verb constructions and in compound clauses are then compared and contrasted in Section 5. The asymmetry between the Subject and Object and more generally between the Subject and the non-Subject functions are discussed in Section 6. The major difference is that the Subject function must be obligatorily expressed in every clause while the other functions need not be overtly realised. The chapter concludes with the suggestion that the wider typological features of a language should be taken into account for a better understanding of the nature of grammatical relations in particular languages and crosslinguistically. 


\section{Argument structure constructions}

Adopting Goldberg's (1995) approach to argument structure constructions, Essegbey (1999) identifies the following verbal argument structure constructions in Ewe:

one-place construction;

nyá-construction

causal two-place construction

non-causal two-place construction

three-place construction

I will discuss the features of each of these constructions in turn. It should be noted however that arguments in Ewe can be either NPs or Postpositional phrases (PostPs). The postpositions that head these Postpositional phrases are not relational markers; rather they code spatial regions or axial parts of objects. They do not have any case marking functions. There are prepositions in the language as well which are relational items (see Ameka 1995, 1996 for the behaviour of prepositions and postpositions in Ewe). Prepositional Phrases do not function as direct syntactic arguments in these constructions. Example (2) shows a sentence with a Postpositional Phrase as its single core argument.
(2) Mó-á dzí pó road-DEF upper surface become wet 'The surface of the road is wet.'

\subsection{The one-place construction}

A one-place construction is defined by Essegbey (1999:99) as an "A[rgument] $\mathrm{S}$ [tructure] C[onstruction] containing one core syntactic argument". The single core argument immediately precedes the Verb Phrase and nothing can intervene between them. Consider the following examples; example (3b) shows that a temporal nominal in adjunct function cannot intervene between the subject and the object.

(3) a. Tsi dza etss water ooze yesterday 'It rained yesterday.'

b. Tsi ( ${ }^{\star}$ etso) dza water yesterday ooze 
Essegbey argues that the semantics of this construction is 'lack of cause'. That is to say that the single syntactic argument is not viewed as being in control of bringing about the state of affairs characterised in the construction. It can be seen as undergoing a change of state or being in a state.

The nyá construction also has one core syntactic argument. It has the form $\mathrm{NP} / \mathrm{PostpP}-n y a ́-\mathrm{V}-(n a$ ' to/for' NP). Nothing intervenes between the single core argument and the verbal complex containing nyá modal. Furthermore, the construction has the general meaning of 'lack of cause' and the core argument is also an Undergoer. More specifically, the verbal complex predicates a property of the single argument (see Ameka 1991:298-339 on the semantics of the construction).

(4) a. Vi mé-nyá dzi-na o

child NEG-MOD bear-HAB NEG

'Child bearing is not easy.'

b. Nyónu-a nyá kpó-ná

wOMan-DEF MOD see-HAB

'The woman is beautiful.'

The nyá construction is paradigmatically related to the causal two-place construction discussed below since the most involved participant in a situation characterised in such a construction is the central participant or the single direct syntactic argument in the nyá construction. This basic intuition is captured in Essegbey's (1999:132) analysis when he claims that in the nyá construction the Causer argument is "shaded", that is, it is no longer profiled in terms of Goldberg (1995:57). The grammatical process that links the nyá construction to the two-place construction has been characterised by Duthie (1996: 110) as follows: "The preverbal auxiliary nyá has the effect of enabling an Object nominal phrase to move from after the Verb to occur before the Verb as Subject. This process could be called inversion or passivization."

\subsection{The two-place construction}

In the causal two-place construction there are two core syntactic arguments, one with more Actor-like properties and the other with more Patient-like properties. These arguments have fixed positions in the construction. Thus the more Actor-like argument which is construed as being in control of bringing about the state of affairs fills the immediate preverbal position. Essegbey assigns the constructional role of Causer to this argument. The other argu- 
ment occurs in the immediate post-verbal position. As is the case in the oneplace construction nothing can intervene between the pre-verbal argument NP and the verb, nor between the postverbal NP and the verb. For example:

(5) a. Kofi du-na akodú yútó

K. eat-HAB banana much

'Kofi eats banana a lot.'

b. Kofi du-na ( ${ }^{*}$ Nútó) akıdú

K. eat-HAB much banana

c. Kofí (*etss) du akodú

K. yesterday eat banana

The causal two-place construction is the familiar prototypical transitive construction from other languages. However, as Fillmore (1970) signalled for English, there are two kinds of transitive constructions in many languages (see DeLancey (e.g. 1995) for a revival of this idea). The non-causal two-place construction proposed by Essegbey for Ewe could be thought of as a second transitive construction. In this construction, the two arguments are in a kind of figure-ground relation. Essegbey calls the construction a "Theme-Locative construction" where the theme is understood as the argument whose location or state is at issue and the Location is broadly conceived to include states, properties and experiences (cf. De Lancey 1995, 1997). Neither argument is construed as controlling or initiating the realisation of the state of affairs characterised in the construction. The sentence in (6a) is an instantiation of such a structure.

(6) a. Nyónu-ví-á dze tugbe yútó woman-DIM-DEF contacted beauty much 'The girl is very beautiful.'

lit: The girl made contact with beauty

b. Nyónu-ví-á dze ( ${ }^{*}$ yútó) tugbe woman-DIM-DEF contacted much beauty

\subsection{The three-place construction}

The last argument structure construction proposed by Essegbey is the threeplace construction which has three core arguments. The semantics of this construction is one of 'caused transfer'. Essegbey (1999:170) notes that: 
There are three specific ways in which the transfer is encoded and each instantiation is dependent on the semantics of the particular verbs. The three senses are represented below:

a. $\mathrm{X}$ causes $\mathrm{Y}$ to undergo a change of location towards $\mathrm{Z}$

b. $X$ causes $Y$ to make contact with $Z$

c. $\mathrm{X}$ causes $\mathrm{Y}$ to be located at $\mathrm{Z}$

For our purposes $\mathrm{X}$ is realised by the NP/PostP that immediately precedes the verb and nothing can intervene between it and the verb phrase. $\mathrm{Y}$ is the NP that immediately follows the Verb and nothing can intervene between it and the verb, nor between it and the second complement - the Z. One can think of $\mathrm{X}$ as the Causer, $\mathrm{Y}$ as the Theme and $\mathrm{Z}$ as the Recipient. Consider this example:

Kofí fíá akónta deví-á-wó

K. teach arithmetic child-DEF-PL

'Kofi taught arithmetic (to) the children.'

Although Essegbey discusses the behaviour of three-place constructions involving the verbs fía 'teach, show', used in the above example, and ná 'give' showing that they can enter into another three-place construction in which the Recipient precedes the Theme, he does not recognise this pattern as a distinct construction. Such a structure is a distinct construction, in my view. Unlike in the first construction, the NP immediately following the verb is the Recipient and the one immediately following it is the Theme as is evident from the example in (8).

\section{Kofí fiá deví-á-wó akónta}

K. teach child-DEF-PL arithmetic

'Kofi taught the children arithmetic.'

Essegbey discusses the differences between the two patterns in particular in relation to symmetric and asymmetric properties displayed by both objects and also in terms of definiteness restrictions that operate between the two objects in the two constructions (see Essegbey 1999: 144-57).

Two points should be noted about the constructional approach to argument structure outlined here. First, a verb can enter any of the constructions once its semantics and its construal with the other members of the construction are compatible. Second, arguments and their compatibility can come from the semantics of the verb or be licensed by the construction. Thus one verb can occur in several of the argument structure constructions. I illustrate 
this with the verb fo which is primarily bivalent and is usually glossed as 'hit, strike' but whose semantics can be roughly characterised as follows (cf. van Aalderen 1997 for an overview of this verb).

(9) Entity X fo Entity Y

An entity $(\mathrm{X})$ makes contact with another entity $(\mathrm{Y})$

because of this

something happens in entity $\mathrm{Y}$

after this

one can say something about entity $\mathrm{Y}$

Consider these examples:

(10) a. Ga fo (one-place construction)

bell strike

'The bell rang.'

b. Kofí fo ga (causal two-place construction)

K. strike bell

'Kofi rang the bell.'

c. Ga lá nyá fo ná Kofí (nyá construction)

bell DEF MOD strike to K.

lit: The bell was ringable to Kofi

(11) a. Tsi fo Kofí (non-causal two-place construction) water strike $\mathrm{K}$.

'Rain fell on Kofi.'

b. * Kofí nyá fo ná tsi (nyá construction)

K. MOD strike to water

(12) Kofí fo tú xeví lá (three-place construction)

K. strike gun bird DEF

'Kofi fired a gun at the bird.'

Space limitations prevent me from demonstrating how the rough semantic paraphrase of the verb fo and the semantics of the constructions plus the semantics of the NPs that function as arguments in them can interact and yield the interpretations of the sentences captured in the free translations. However, if one considers the interpretation of example (10a), the one-place construction, the main point is that the constructional meaning 'lack of cause' cancels out the causal part of the meaning of the verb, namely, 
An entity (X) makes contact with another entity (Y) because of this

This leaves the rest of the components, which when fleshed out leads to the interpretation 'the bell rang'. I will now turn to the marking of grammatical relations.

\section{The marking of grammatical relations}

\subsection{Constituent order}

It should be clear from the discussion of the argument structure constructions that grammatical functions in Ewe are marked by constituent order. In all the constructions discussed which can function as utterances by themselves there is an argument that occurs in the immediate preverbal position. This argument functions as the starting point for the rest of the basic utterance (cf. Mithun and Chafe 1999). This argument has the Subject function in the language. There is no grammatical construction in which the Subject occurs after the verb. There is no subject-verb inversion construction. This means that we can describe grammatical relations configurationally with respect to the verb. The linear order of the arguments and their relations in a pragmatically unmarked clausal construction is:

(13) NP/PostP-V-NP/PostP-NP/PostP-Other

Subject Object1 Object 2

\subsection{Pronominal forms}

Apart from constituent order which distinguishes between the core arguments in a basic clause, the subject is distinguished from the non-subject relations by the form of pronominal clitics that are used to express them. Thus while there is a distinct paradigm for the subject the same paradigm applies to Object1 and Object 2 and even to a prepositional object which is not a clause level argument.

Note that there are even two forms for the subject pronouns which are distinct for the 2nd and 3rd person singular. The uses of the second subject pronoun forms will be discussed in Section 5 below. To illustrate the way the 
Table 1. Ewe personal pronouns

\begin{tabular}{|c|c|c|c|c|c|c|}
\hline & \multicolumn{3}{|c|}{ Singular } & \multicolumn{3}{|l|}{ Plural } \\
\hline & $\begin{array}{l}\text { 1st } \\
\text { person }\end{array}$ & $\begin{array}{l}\text { 2nd } \\
\text { person }\end{array}$ & $\begin{array}{l}\text { 3rd } \\
\text { person }\end{array}$ & $\begin{array}{l}\text { 1st } \\
\text { person }\end{array}$ & $\begin{array}{l}\text { 2nd } \\
\text { person }\end{array}$ & $\begin{array}{l}3 r d \\
\text { person }\end{array}$ \\
\hline $\begin{array}{l}\text { Subject } \\
1 \text { st form } \\
2 \text { nd form }\end{array}$ & $\mathrm{m}(\mathrm{e})$ & $\begin{array}{l}\mathrm{e} \\
\mathrm{n}(\mathrm{e})\end{array}$ & $\begin{array}{l}\text { é } \\
\text { wò }\end{array}$ & mí(é) & $\operatorname{mi}(\mathrm{e})$ & wó \\
\hline Object & $\mathrm{m}$ & wò & $\mathrm{i}, \mathrm{e}, \mathrm{E}$ & mí & $\mathrm{mi}$ & wó \\
\hline Free form & nye & wò & é(ya) & míá(wó) & mia(wó) & wó(áwó) \\
\hline
\end{tabular}

pronominal forms reinforce the constituent order definition of grammatical relations compare the following text examples:
a. Subj
Obj PObj Obj PObj
Me-de kúkú ná wò, gblo-e ná-m
1sG-remove hat to $2 \mathrm{sg}$ say-3sg to-1sg
'I beg you tell (it to) me.' (Agbezuge 953)
b. Subj
Obj Subj
Obj
Éya yútó dó-á dzo éye wò-da-a
é-fé hiã-nú
3sG very set-HAB fire and 3sG-cook-HAB 3sG-poss poor-thing
du-na. (Agbezuge 2263)
eat-HAB

'He himself sets fire and cooks his own poor meal to eat.'

In example (14a) we have two instances of the first person pronoun: once as subject $m e$ and the other as the prepositional object $m$. Both forms are distinguished. Needless to say, the prepositional object form would be used for the direct object form as well. There is also an instance of the object form of the second person pronoun as a prepositional object wò. One of the realisations of the third person singular object as $e$ is also present in this example. In exmple (14b) we have the strong form of the 3sG independent pronoun éya and the weak form in the possessive phrase éfé. There is also the second form of the 3sG subject pronoun wòn used in the second clause just after the conjunction éye 'and'.

\subsection{Emphatic subject construction}

Even though NPs with any grammatical relation can be emphasised using 
members of the word class Intensifiers, when such structures bear the subject grammatical relation, there is a distinct construction used. This distinct emphatic subject construction sets the subject function apart from the other relations. In this construction the subject NP is modified by an intensifier. Intensifiers constitute a distinct word class in Ewe and include items equivalent to what have been called focus particles in other languages. For example, hâิ 'also, too', ya 'as for', kátấ 'all', boy 'rather' kúráá 'even' and yút 't 'very'. Furthermore, if the emphasised subject is first or second person, it is recapitulated on the verb with the appropriate pronominal clitic. The recapitulation by pronominal clitic is optional for the third person plural. The emphatic third person singular subject is never recapitulated. Compare the following examples:
a. deví-á-wó hấ (wó)-f́́
child-DEF-PL too 3PL-wake up
'The children too (they) are fine.'
b. Nye yútó me-wo-e
$1 \mathrm{sg}$ very $1 \mathrm{sg}-\mathrm{do}-3 \mathrm{sg}$
'I myself I did it.'
c. Kofí ya (*é/* wò) dzó
K. as for $3 \mathrm{SG}$ leave
'Kofi, on the other hand, left.'

\subsection{Additive NP as subject construction}

The emphatic subject construction described above is similar in some respects to the additive NP subject construction. In these constructions if the conjuncts involve the first or second person, then they are recapitulated on the verb in the appropriate pronominal form. In this case too the pronominal recapitulation on the verb is optional for the third person, as illustrated in (16) below.
(16) Kofí kplé Áma (wó)-yi tó
lá dzí
K. LINK A. 3PL-go mountain DEF upper surface
'Kofi and Ama (they) went to the top of the mountain.'

To sum up, constituent order distinguishes the core grammatical relations of subject, object and second object. Pronominal forms for the expression of these relations are distinguished on the basis of Subject vs. non-subject or object relations. In addition we have seen that certain constructions are 
described with respect to the grammatical function of Subject. The expression of the functions in various constructions shows similar clustering where the Subject is treated apart from the Object or the Subject and Object are treated in similar fashion. These properties are discussed next.

\section{The expression of the relations in morpho-syntactic structures}

Various properties both identify and distinguish the grammatical relations of Subject, Object and Second Object as defined configurationally in their expression in different morpho-syntactic structures. The expression of these functions in nominalisation structures, focus constructions and relative constructions are discussed in this section.

\subsection{Nominalisation}

In clausal nominalisation of the gerundive type, the Subject is expressed as the possessor in an alienable possessive structure. That is to say the NP or Postpositional phrase representing the subject is linked to the rest by the possessive connective fé. Direct Object nominalisation, however, involves preposing the object NP to a reduplicated verb. There is just juxtaposition. The Second Object will always occur in apposition to any of the structures of Subject or Direct Object nominalisation. Compare the two expressions below where (17b) is the nominalisation of $(17 \mathrm{a})$,
a. Kofí ná ga Kwami
$\mathrm{K}$. give money $\mathrm{K}$
'Kofi gave Kwami money.'
b. Kofí fé ga-ná-ná Kwami
K. Poss money-RED-give K
'Kofi's money giving to Kwami.'

While realisation in nominalisation distinguishes between Subject and Object, the strategy involving the Second Object realisation does not distinguish it from the expression of other peripheral complements. Such elements also just occur postposed. Compare (18a) in which the temporal noun etss 'a day from today' is not a direct argument but an adjunct with its nominalisation in (18b). Note that the noun etso 'a day from today' occurs in the same position as Kwami, the second object in (17b). 
(18)

a. Kofí dzó etso

K. leave a day from today

'Kofi left yesterday.'

b. Kofí fé dzo-dzó etso

K. poss RED-leave a day from today

'Kofi's leaving yesterday.'

\subsection{Relativisation}

Relativisation processes also show differences between the expressions of the grammatical relations (see Dzameshie 1983; Lewis n.d.). Subject and Object relativisation do not employ a marker strategy. Relativisation involving the Second Object, however, uses a marker strategy. This marker has been dubbed the RELative-i by Lewis (n.d). This label characterises only one specific function of the form as Lewis himself acknowledges. A similar marker is involved in other constructions such as focus constructions (Ameka 1992) and in serial verb constructions (e.g. Collins 1993). It could just be considered an invariable form that occurs in these constructions. It is invariable because it does not have any person and number features associated with it (see example (21c) below).

Relative constructions in Ewe have a sort of discontinuous structure. A simple NP in Ewe has the structure

(Identifier) N/Pro (Qualifier) (Quantifier) (DET1)(DET2)(PL) (INT)

An example of an NP with several slots filled is given in (19).

Identifier N Qualifier Quantifier DET2-PL INT
neném nya véví eve
such má-wó ko
'only these two important issues.'

DET 1 slot is filled by the definiteness marker or the particularised indefiniteness marker. The DET2 slot, on the other hand, is filled by demonstratives or the content question marker $k a$ 'CQ'or the relative marker $s i$ 'REL'. Crucially for our present purposes, in an NP containing a relative clause the relative clause introducer occurs in its place in the NP structure and if the PLural and/or the intensifier slots are filled they will come before the rest of the relative clause. There are co-occurrence restrictions between the elements that fill the various determiner slots accross dialects. For instance while DET1 and 
DET2 slots are mutually exclusive in the standard and in the southern dialects, in the inland dialects the fillers of these slots can co-occur. For illustrative purposes I concentrate on an expression in which the last two elements as well as DET2 in the NP is filled.

(20) $\left[\mathrm{N}\right.$ DEt2-PL INT $\left[\begin{array}{lll}\mathrm{V} & \mathrm{N} & ]\end{array}\right] \mathrm{TP} \mathrm{V}$ Obj.

deví si-wó kátấ tsí megebé lá xo tóhehe

child REL-PL all stay back TP get punishment

'All the children who were late were punished.'

Now compare the various relative constructions in which the head NP has the Subject, Object and second Object relation in the relative clause.

(21) a. Subject relativisation

Kofí si da tú xeví lá...

K. REL throw gun bird TP

'Kofi who fired a gun at the bird.'

b. Object relativisation

Tú si Kofí da xeví lá

gun REL K. throw bird TP

'The gun which Kofi fired at the bird.'

c. Second object relativisation

xevi si Kofí da tú-i lá

bird REL K. throw gun-INV TP

'The bird at which Kofi fired a gun.'

As noted above in the case of Second Object relativisation a marker strategy is used but the fillers of the Subject and Object role are relativised in similar fashion. In the next section parallel structures in focus constructions are described.

\subsection{Focus constructions}

Some formal differences show up in focus constructions depending on the grammatical relation of the NP argument that is in focus. The argument focus construction, as opposed to the predicate focus construction, has the basic structure of the argument in focus, which is optionally marked by the argument focus marker $-(y)$ é, occurring first followed by the rest of the clause (without any intonational break, see Ameka 1992, to appear). I demonstrate below how the various nominal phrase constituents in example (22) may be focussed. 


\section{(22) SUBJ VERB OBJ1 OBJ2}

Núfíalá ná dó suku-ví-á-wó

teacher give work school-child-DEF-PL

'Teacher gave work to the pupils.'

If the Subject of a simple clause is focussed it is obligatorily marked with the focus particle $(y) e$. The presence of the focus marker is the only difference between a clause with unmarked focus such as (22) above and a clause whose subject is marked for focus as in (23):

(23) Núfíalá-é ná do suku-ví-á-wó teacher-aFoc give work school-child-DEF-PL 'TEACHER gave work to the pupils.'

If the subject NP is focus marked, the scope of focus can be over only the NP that bears that relation or it can be over the whole clause. If the focussed argument bears the direct object relation, then the focus marker is optional. There is no other marker in the construction to indicate that the fronted NP bears the Object relation. Furthermore, if the scope of focus is wider than just the NP argument in focus position, it is never over the whole clause. It may be over the predicate phrase, that is the verb and the object. Consider this example:

Do-é núfíalá ná suku-ví-á-wó

work-aFoc teacher give school-child-DEF-PL

'WORK teacher gave to the pupils.'

When the second object is the argument that is in focus, it is also preposed to the rest of the clause and the focus marker is also optional in this case. However, there is another marker, the invariable-i marker that we saw in the Second Object relativisation construction in Section 4.2, optionally present in the rest of the construction as is shown in the example below.

$$
\begin{aligned}
& \text { Suku-ví-á-wó-é núfíalá ná dó(-e) } \\
& \text { school-child-DEF-PL-AFOc teacher give work-INV } \\
& \text { 'THE PUPILS teacher gave work.' }
\end{aligned}
$$

It should be noted that if the resumptive marker agreed with the NP that is in focus, then we would expect the third person plural pronoun form wó, which is ruled out in this example. Thus the morpho-syntactic behaviour of NP arguments in focus constructions shows differences with respect to the grammatical relation they bear in the clause. 


\subsection{Summary}

Table 2 is a summary of the defining properties of the various grammatical relations and their expression in various morpho-syntactic constructions.

Table 2. A comparison of the grammatical relations

\begin{tabular}{|c|c|c|c|}
\hline Feature & Subject & Direct object & Second object \\
\hline Linear order & $\begin{array}{l}\text { Immediately } \\
\text { precedes the verb }\end{array}$ & $\begin{array}{l}\text { Immediately follows } \\
\text { the verb }\end{array}$ & $\begin{array}{l}\text { Immediately follows } \\
\text { the Direct Object }\end{array}$ \\
\hline $\begin{array}{l}\text { Pronominal } \\
\text { paradigm }\end{array}$ & $\begin{array}{l}\text { Distinct from the } \\
\text { one for Object; plus } \\
\text { a subset of distinct } \\
\text { forms for some } \\
\text { persons }\end{array}$ & $\begin{array}{l}\text { Distinct from the } \\
\text { one for subject }\end{array}$ & $\begin{array}{l}\text { Same as the one } \\
\text { for Object }\end{array}$ \\
\hline Nominalisation & $\begin{array}{l}\text { The possessor in } \\
\text { alienable possessive } \\
\text { structure }\end{array}$ & $\begin{array}{l}\text { Preposed and } \\
\text { juxtaposed to } \\
\text { reduplicated form } \\
\text { of the verb }\end{array}$ & $\begin{array}{l}\text { Postposed to DO plus } \\
\text { reduplicated verb } \\
\text { structure }\end{array}$ \\
\hline $\begin{array}{l}\text { Is there a distinct } \\
\text { emphatic construc- } \\
\text { tion }\end{array}$ & Yes & No & No \\
\hline $\begin{array}{l}\text { Relativisation } \\
\text { strategy }\end{array}$ & No marker & No marker & An invariable marker \\
\hline Focussing strategies & $\begin{array}{l}\text { Obligatory } \\
\text { focus marker }\end{array}$ & $\begin{array}{l}\text { Optional } \\
\text { focus marker }\end{array}$ & $\begin{array}{l}\text { Optional focus } \\
\text { marker plus optional } \\
\text { invariable marker }\end{array}$ \\
\hline
\end{tabular}

\section{Clause combining and grammatical relations}

Languages have various mechanisms for keeping track of NPs that are coreferential within the same clause or across clause boundaries. One common strategy that is employed is the omission of the second NP under identity with the first. However languages vary in how far they allow this. In particular, some languages allow that kind of omission if and only if the NPs involved bear certain grammatical relations. For instance, the second occurrence of a common NP in coordinate structures in English can only be omitted if the NPs are the realisation of the Subject in both clauses. In this section, I discuss 
the way Ewe handles the expression of coreferential NPs across clause boundaries. I concentrate on three construction types: the be 'SAY' construction, the overlapping clause and the serial verb construction.

\subsection{The be 'SAY' construction}

In the bé construction, the second occurrence of a common NP is not omitted. It must be obligatorily expressed. Furthermore, there is a pronominal form dedicated to this function which does not vary in form for second or third person. The form is ye and it is called a logophoric pronoun (cf. Clements 1975; Essegbey 1994). There is no special form for the first person. Plural number is marked on the logophoric pronoun by suffixing the plural marker wó to it (ye-wó). The following examples show the use of the logophoric pronoun in the dependent clause where the controller NP in the matrix clause has the grammatical function of Subject. These examples also show the person and number features of the pronoun.
a. Kofi dí bé ye-a-dzó
K. want SAY LOG-SUBJUNCT-leave
'Kofi wants to leave.'
b. $\grave{\mathrm{E}}_{\mathrm{i}-\mathrm{d}}$ bé $\mathrm{ye}_{\mathrm{i}}$-a-dzó-a?
2sG-want SAY LOG-SUBJUNCT-leave-QP
'Do you want to leave?'
c. deví-á-wóo dí bé ye-wó ${ }_{i}$-a-dzó
child-DEF-PL want SAY LOG-PL-SUBJ-leave
'The children want to leave.'

Compare:
d. Me-dí bé m-á-dzó
1sG-want SAY 1sG-SUBJUNCT-leave
'I want to leave.'

The context characterised in the examples in (26) is a favourite one for the so called Equi NP deletion in other languages like English. In Ewe such a context does not trigger Equi NP deletion.

The logophoric pronoun is used in reportive contexts to designate the individual(s) (except for the first person) whose speech, thoughts, feelings, intentions and so on are reported or reflected in the linguistic context. It occurs in grammatical or discourse dependent contexts usually in clauses 
introduced by the dependent clause introcucer bé(ná) 'SAY'. The trigger of the logophoric pronoun in the matrix clause can also have the Object grammatical relation. Consider the following example from Clements (1975:163 ex.57a).

$$
\begin{aligned}
& \text { Dzi dzo Ama be } \mathrm{ye}_{\mathrm{i}}-\mathrm{dzi} \text { vi } \\
& \text { heart straighten Ama SAY LOG-bear child } \\
& \text { 'Ama was happy that she bore a child.' }
\end{aligned}
$$

Thus it does not matter which grammatical relation the NPs that are coreferential bear. It should be noted however that it is Object NPs which are experiencers that control the use of the logophoric pronoun in the dependent clause. In the dependent clause constructions, therefore, there is no omission of NPs that are common across the clauses.

\subsection{The compound or overlapping clause}

In the compound clause, on the other hand, the omission of an NP that is coreferential with another in the first clause does occur. However, this only occurs if the NP bears a non-subject grammatical relation in that clause. The subject argument of the second clause has to be obligatorily expressed. Typically, these structures involve a topic switch and therefore the NP in the subject grammatical role in the second clause is usually coreferential with a non-subject argument expression or with the event expressed in the first clause. These clauses have usually been described in the Ewe linguistic literature in terms of those exemplars where the subject of the second clause is coreferential with the object of the first. Thus Duthie (1996:36) says: "The compound or overlapping type of clause [...] consists of two Verb phrases, but each of them is preceded by its own nominal phrase Subject, the second of which being usually the Object of the first VP" (cf. also Westermann 1930: 136). Consider example (28):

(28) Object of first clause $=$ Subject of second clause

É-fo-m $\quad *(m e)$-dze anyí

3sG-strike-1sG 1sG-contact ground

'S/he hit me I fell down.'

But, in fact, these constructions are of various types. Compare example (28) with (29) in which the NPs realising the Object arguments in both clauses are coreferential. Note that the subject pronoun of the second clause here can be interpreted as referring to the event expressed in the first clause. 


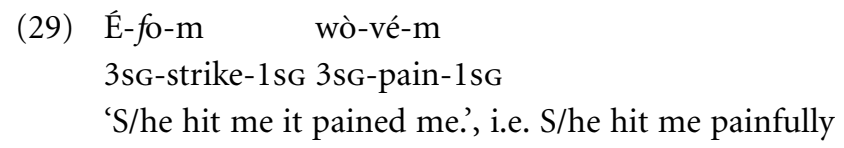

As I indicated above, a defining feature of the construction is that the NP with the subject grammatical role in the second clause must be obligatorily expressed (even if it is coreferential with another NP in the first clause). I will show below that this is the difference between this construction and the serial verb construction. If the NP that bears the object relation in the second clause is coreferential with any argument in the first clause, it may be omitted. Consider these examples

(30) Subject of first clause $=$ Object of second clause

Mólu-a bí wó-du

rice-DEF becooked 3PL-eat

Lit: 'The rice cooked they ate.'

(31) Direct object of first clause $=$ Direct object of second clause

a. dE mí-du cook:3sg 1PL-eat

Lit: 'Cook it we eat.' (a line from children's rhyme)

b. Núfíalá ná dó suku-ví-á-wó wó-wo teacher give work school-child-DEF-PL 3PL-Do

Lit: 'Teacher gave work to the pupils they did.'

In some cases the omitted NP that bears the Object relation in the second clause is coreferential with the event expressed in the first clause. For example:

(32) Xeví-á xló me-se

bird-DEF chirp 1sG-hear

Lit: 'The bird chirped I heard.'

Another feature of these constructions is that they are usually juxtaposed without a connective although in an imperative subtype a jussive or imperative clause introducer né may be used as a linker. They are distinct from coordinate clauses which are conjoined by éye 'and'.

(33) Wo-e né mí-kpó

do-3SG Juss 1 PL-see

'Do it let's see.'

The compound clause construction, therefore, shows a distinction between 
Subject and Object in terms of the expression of these roles in the second clause. The relationship between the two clauses in the compound clause construction could be either consecutive or simultaneous in time. The crucial feature is the topic shift and the obligatory expression of the subject is an indicator that the two clauses do not share the same subject or topic. It has been suggested that the second form of the subject pronouns used in such clauses are the relics of a switch reference system (Lewis 1999). This is one difference between the compound clause construction and the serial verb construction, as will be shown below.

Another feature of the compound clause construction which distinguishes it from the serial verb construction is that each clause can be independently negated. More importantly, the second clause can be independently negated of the first. Mostly if the first verb is negated it has scope over the whole construction. This is partly signalled by the placement of the second discontinuous element of the negative morpheme $o$. Compare the following pair of sentences:

$$
\begin{aligned}
& \text { a. Me-yó-e mé-to o } \\
& \text { 1sG-call-3sg 3sG:NEG-respond NEG } \\
& \text { 'I called him he didn't respond.' } \\
& \text { b. Nye-me-ý́-e wò-to o } \\
& \text { 1sG-NEG-call-3sg 3sG-repond NEG } \\
& \text { 'I didn't call him he didn't respond.' }
\end{aligned}
$$

In (34a) only the second clause is negated; the first clause is not. In (34b) the scope of the negation is over both clauses. The scope of the negative in (34b) could also be narrower and be just on the first clause but extended to the second clause by inference. As we shall see below, by contrast, the serial verb construction can only be formally negated as a whole; no individual verb in the series can be independently negated.

\subsection{Serial verb construction}

A serial verb construction in Ewe is a monoclausal construction in which there are two or more verbs in sequence sharing the same subject and each of them appearing with other arguments of their own. Some of the non-subject arguments may be shared but need not be. The tense-aspect values of each verb should be semantically compatible. Unlike the compound clause, the first part of the discontinuous negative morpheme always has to occur with the 
first verb and none of the verbs can be independently negated. As Lord (1993: 1) points out, "defining serial verb constructions is a sticky business". This applies in a way to both finding cross-linguistically valid characterisations as well as language-specific delimitation of the construction. This is because serial verb constructions (SVC) tend to be a subtype of multi-verb constructions. In what follows serial verb constructions in Ewe are described and the way they differ from the overlapping clause; a closely related multi-verb construction will be highlighted. The expression of the core grammatical relations in the SVC will also be compared with their expression in the overlapping clause.

One of the defining features of a serial verb construction that is usually presented is that the verbs in an SVC are not linked by any overt marker of coordination or subordination (cf. Dechaine 1993; Durie 1997; Aikhenvald 1999). The crucial point for Ewe is that serial connectives occur but they are not sentential level connectives (cf. Crowley 1999). Arguably, the two serial connectives are erstwhile verbs and thus could have evolved from verbs in serial structures into connectives (Westermann 1930). Thus in some SVCs, the following serialising connectives may be used to link the verbs- $d a$ for consequential and usually purposive relations and hé for indicating simultaneous or sequential relations between the verbs in a series. ${ }^{3}$ Consider the following examples in which the connectives occur.
a. Bokś de hūū hé-vúvú ta diviner remove groan ConN-shake head 'The diviner groaned and shook his head.' (Kwamuar 1997:22)
b. É-yi agble da-ku te
3sG-go farm conN-dig yam
'He went to the farm and dug yams.'

Another issue in the definition of SVCs concerns the claim that the verbs in the construction share the same tense-aspect value. In fact, one of the earliest statements on this matter is given by Schachter (1974). He states the constraint as follows:

There is no independent choice of tense or aspect for the several verb phrases that occur in a serial construction. Instead once the tense aspect value of the first verb is specified, that of all subsequent verbs is determined. (Schachter 1974:259)

Even though Schachter's phrasing could be interpreted in other ways, he interprets it in terms of either the repetition of the same tense-aspect marking 
on each verb in the series, as in Akan, or in terms of tense-aspect value being specified once, as in Yoruba. In my view Schachter's original characterisation is nearer the truth than his interpretation. In Ewe, and incidentally in Akan as well, the verbs in a series can be marked for different tense-aspect categories provided they are semantically compatible. In this sense once the tense-aspect value of the first verb is specified that of the subsequent verbs is determined. Thus if the first verb is unmarked for tense-aspect then the second will also be unmarked as in (36a). If the first is marked for the potential then the subsequent verb is also marked for the potential as in (36c) or for unmarked aspect as in (36b). In that case, the interpretation of the temporal frame of the second verb is dependent on that of the first, and in that sense, there is no independent choice of tense-aspect marking. Consider the following sentences:

(36) a. Áma da fufu du

A. cook fufu eat

'Ama cooked fufu and ate.'

b. Áma a-da fufu du

A. вот-cook fufu eat

'Ama would cook fufu and eat.'

c. Áma a-da fufu á-du

A. гот-cook fufu рот-eat

'Ama would cook fufu and will eat.'

d. Áma le tsa-tsa-ḿ

A be at:PRES RED-wander-PROG

le gbe dó-ḿ ná ame-wó

be at:PRES voice put-PROG to person-PL

'Ama is moving about greeting people.'

Languages, and even dialects, vary with respect to whether sentences of the kind in (36c) satisfy the criteria for SVC in those particular varieties. In his analysis of Kpelegbe, a dialect of Ewe spoken in Togo, Collins (1993, 1997) argues that such structures are not serial but rather cases of verbal parataxis or covert coordination. SVCs in Kpelegbe are restricted to those in which there is only one marking of the potential as in (36b). His approach restricts the marking of tense-aspect categories to only once in the SVC. Collins (1997:464, note 5), however, acknowledges in a footnote that his analysis does not extend to the dialects of Ewe spoken in Ghana becauses in these dialects the test of single marking of future time does not hold. Actually, in Anlo - the southern dialect of Ewe where the prospective construction instead of the potential is 
used to express 'future', the equivalent of sentence (36b) would have to be similar in structure to sentence (36c) since the first verb will be in the prospective and the second verb would have to be obligatorily marked for the potential, as in (37) (cf. Essegbey to appear).

(37) Áma le nú da gé *(á)-du

A. be at:PRES thing cook PROSP POT-eat

'Ama will cook and eat.'

Such structures meet all other criteria for SVCs in Ewe, I therefore consider them SVCs. Other sentences in which the verbs in the series only have to be semantically compatible but not be identically marked for the same thing are those in which the first verb expresses a state and the second verb overlaps with the temporal frame set up by the first. Thus the first verb could be an inchoative verb in the unmarked aspect with a stative interpretation and the second verb can be in the progressive, as in $(38 \mathrm{a}, \mathrm{b})$.
a. Wó-dze klo le
gbe dó-m' dá
3PL-contact knee be at:PRES voice put-PROG DIR

'They came to be in a kneeling position and are praying.'

b. É-le te-wò fé dzodófé le akple du-ḿ SG-be at aunt-2sG POss kitchen be at:PRES dumpling eat-PROG 'He is in your aunt's kitchen eating dumpling.' (Kwamuar 1997:36)

What seems crucial for the definition of SVCs with respect to tense-aspect marking is the semantic compatibility and in cases where there is no identity in marking, the verbs must be interpretable as overlapping in time. Evidence for this claim comes from the behaviour of verb sequences involving activities in which the first verb is in the progressive. If the second verb is also in the progressive then the structure is a true SVC. Note, however, that such a structure has an interpretation in which the situations characterised by both verb phrases occur repeatedly yet simultaneously in time. For instance:

(39) Áma le nú da-ḿ le du-du-ḿ

A. be at:PREs thing cook-PROG be at:PRES RED-eat-PROG

'Ama is cooking and eating.'

The interpretation of the above sentence (39) is that Ama has been cooking and eating. However if the cooking and eating are not construed as overlapping in time but subsequent to each other then a non-SVC structure is used and in that case the second verb phrase does not occur in the progressive, as in (40). 
(40) Áma le nú da-ḿ bé ye-a-du

A. be at:Pres thing cook-PROG PURP LOG-POT-eat

'Ama is cooking to eat.'

I suggest that temporal overlap is a sufficient feature that drives the varying tense-aspect marking on verbs in an SVC. As pointed out earlier, this is not a necessary feature of compound clauses.

SVCs, as noted earlier, also differ from overlapping clauses in that the verbs cannot be independently negated. In an overlapping clause the second verb can be negated independently of the first, as illustrated in example (34) above. That is to say, the verbs do not have to agree in polarity. In an SVC the polarity of the subsequent verbs is dependent on that of the first verb. Recall that in Ewe, standard or clausal negation is marked by a discontinuous morpheme mé...o where the mé occurs verb phrase or predicate initially and the $o$ occurs at the end of the clause but before any occurring utterance final particles. In an SVC the mé occurs with the first VP and the o occurs at the end of the whole series. This is why example (41b) below is unacceptable since $o$ occurs after the first verb in the series. Formally, then, the scope of negation is over the whole SVC clause. In terms of interpretation, however, the scope of the negation can be narrower and be over only one verb. Thus in (41c) below, even though the formal scope of the negation is over the whole SVC in the first clause, its scope seems to be over only the first verb phrase since its assertion can be corrected by a following predicate focus clause. Consider these examples:

(41) a. Áma mé-da nú du o

A. NEG-cook thing eat NEG

'Ama did not cook and eat.'

b. *Áma mé-da nú o du 'Ama did not cook eat.'

c. Áma mé-da nú du o, de wò-fle nú du

A. NEG-cook thing eat NEG pFoc 3sG-buy thing eat

'Ama did not cook and eat, she BOUGHT something and ate.'

d. Áma da nú mé-du o

A. cook thing NEG-eat NEG

\#Ama cooked didn't eat (SVC interpretation unacceptable)

'Ama cooked s/he (i.e.someone else) didn't eat it.'

(Overlapping clause interpretation) 
Recall that in the negative, the $3 \mathrm{sg}$ form is zero hence the possibility to interpret (41d) as an SVC where the subject of the second verb is unexpressed under the same subject constraint.

Now, we turn to the expression of core grammatical relations in SVCs. In discussions of SVCs in the literature the consensus seems to be that verbs in an SVC should share the same subject. Some authors have further assumed that the verbs in the construction should also share objects (Baker 1989; Campbell 1996; Collins 1997); while others add that the verbs should share one nonsubject argument (Durie 1997; Aikhenvald 1999). Stewart (1998:320) is the most vocal and asserts that "In a serial verb construction the verbs must share external and internal arguments". The only requirement for the verbs in an SVC in Ewe in this regard is that they should share the same grammatical subject. Furthermore, the subject is expressed only once in the construction at the beginning of the structure. As noted earlier this is the crucial difference between an SVC and an overlapping clause. In a compound clause the subject of subsequent verbs need not be the same and it must be obligatorily expressed. This difference is also related to the fact that the SVC is a monoclausal structure while the compound clause is a multi-clausal structure. Consider the following minimal pair:
a. É-yó deví-á-wó fo fú (SVC)
3sG-call child-DEF-PL hit bone
'S/He called the children together.'
b. É-yo deví-á-wó wó-fo fú (Overlapping clause) 3sG-call child-DEF-PL 3PL-hit bone
'S/He called the children (and) they gathered together.'

The minimal difference between the two utterances is that in (42b) the subject of the second verb is expressed and it is coreferential with the Object NP of the first verb. In (42a), on the other hand, the action denoted by the first verb is construed to be performed by the same participant which is realised as the subject argument of the first verb. A further piece of evidence for the difference between the two is that the sentence in (42a) can be continued with a goal prepositional phrase containing a 3sG-reflexive complement. This is not possible for the sentence in (42b) because of the number of its Subject, which shows that there are differences in the expression of the Subject for the two verbs. Consider these counterparts of $(42 a, b)$ in (43): 
(43) a. É-yó deví-á-wó fo fú dé é-dókui gbó (SVC) 3sG-call child-DEF-PL hit bone ALL 3SG-REFL environs

'He called the children together beside himself.'

b. É-yó deví-á-wó wó-fo fú dé é-( ${ }^{\star}$ dókui) gbó (Overl.) 3sG-call child-DEF-PL 3PL-hit bone ALL 3SG-REFL environs 'He called the children they gathered together beside him( ${ }^{*}$ self).'

Thus the subject argument is expressed only once in an SVC while each verb in a compound clause must have its subject argument expressed.

Similarly, if the verbs in an SVC share the same Object NP then the subsequent occurrence of the NP is omitted. For example, the NP te 'yam' in the sentence in (44) functions as the Object, and for the three verbs. However, it is expressed only once with the first verb.

(44) É-ku te da du 3sG-scoop yam cook eat

'He dug yams cooked and ate.'

However, each verb can have its own object NP expressed. This occurs when the first verb is semantically monovalent but the others are multivalent as in (45a). It also occurs in cases where the verbs involved in the SVC are obligatory complement taking predicates as in (45b) (see Essegbey 1999). Thus the strict transitivity character of Ewe affects the issue of shared arguments and the realisation thereof in an SVC.

(45) a. É-f́́ yi to me 3sG-rise go river containing region of

'S/he woke up and went to the river side.'

b. deví-á ku tsi kló ykúme child-DEF scoop water wash face 'The child drew water and washed (his/her) face.'

Recall that in compound clauses when two NPs in Object function are coreferential in both clauses the second occurrence may be omitted, as in (46).

(46) É-ku te ná Áma wò-da

3sG-scoop yam for A. 3sG-cook

'He dug yams for Ama and she cooked.'

This means that in terms of the omission of the expression of coreferential NPs in Object function, the SVC and the compound clause construction are 
alike. The crucial difference between the two constructions is in the expression of the Subject function.

5.4 The serial verb construction and the overlapping clause compared

Table 3 summarises the similarities and differences between the SVC and the compound clause.

Table 3. Comparison between serial verb construction and the overlapping clause

\begin{tabular}{|c|c|c|}
\hline Features & Serial verb construction & $\begin{array}{l}\text { Compound/ } \\
\text { overlapping clause construction }\end{array}$ \\
\hline $\begin{array}{l}\text { Material occurs } \\
\text { between verbs }\end{array}$ & + & + \\
\hline $\begin{array}{l}\text { Each verb can surface } \\
\text { with its own non- } \\
\text { subject argument }\end{array}$ & + & + \\
\hline Connectives can occur & + & $-/+($ né IMP) \\
\hline $\begin{array}{l}\text { Subject argument of } \\
\text { each verb can be } \\
\text { overtly expressed }\end{array}$ & - & + \\
\hline $\begin{array}{l}\text { Each verb can be } \\
\text { independently negated }\end{array}$ & - & + \\
\hline $\begin{array}{l}\text { Temporal overlap } \\
\text { construal }\end{array}$ & + & - \\
\hline Level of juncture & Core & Clause \\
\hline
\end{tabular}

\section{Subject and Object asymmetry}

From the survey of the expression of grammatical relations, especially of Subject and Object, the two core arguments in a transitive clause, in Ewe, the picture that emerges is that the NP bearing the Subject grammatical relation in a clause must be obligatorily expressed. The obligatoriness of the Subject expression applies also to expletive pronouns which have a Subject function. Under certain conditions however, the Object relation expression can be omitted. Significantly, expletive pronouns that have Object function in a clause can 
also be omitted. Expletive pronouns have cataphoric functions and they tend to occur in complement clause constructions. One context for the use of such pronouns in Subject function is in those structures involving emotional and value judgement. Such pronouns refer, as it were, to the complement clauses and they cannot be left out. Consider these examples.
a. É-nyó bé nè-vá
3sG-be good SAY 2sG-come
'It is good that you came.'
b. É-dzo dzi ná Áma bé ye dzi vi
3sG-straighten heart for A. SAY LOG bear child
'It pleased Ama that she gave birth to a child.'

The second set of constructions where we find such cataphoric pronouns in Subject function is in modal constructions for the expression of necessity or obligation, as in (48).
a. É-le
bé mia-vli
vévie
3sG-be at:PRES SAY 2PL:SUBJUNCT-strive steadfastly
'It is that you should strive steadfastly.'
b. É-dze bé deví-wó ná-bu wó dzilá-wó
3sG-fit SAY child-PL SUBJUNCT-respect 3PL parent-PL
' (It is fitting that) children should obey their parents.'

An expletive cataphoric pronoun in Subject function also occurs in constructions that express 'apparent' situations as illustrated in (49).
É-wo abé tsi le
dza-dza gé
3sG-do like water beJat:PRES RED-OOZe PROSP
'It looks as if it is about to rain.'

Finally, when the verb susı 'remain' occurs in a non-causal two-place construction, the argument in Subject function which is licensed by the construction is expressed as an expletive pronoun. Compare the following pair of sentences.
a. Nya deká suso má-gblo ná wò word one remain 1sG:SUBJUNCT-say to 2 sg 'There is one more thing I should tell you.'
b. É-suss nya deká má-gblo ná wò 3sG-remain word one 1sG:SUBJUNCT-say to $2 \mathrm{sG}$ 'It remains one more thing I should tell you.'


In all cases, these cataphoric expletive pronouns in Subject function cannot be omitted. Similar pronouns can have Object function but in this case they may be omitted as indicated in the examples in (51).
a. Tsi-dza-dza wo-(e) bé núkú-wó nyó water-RED-ooze do-3sg SAY crop-PL bejgood
'Rain made it that the crops grew well.'
b. É-gblo-(e) ná-m bé mie-vá dí-m
3sG-say-3sg to-1sG SAY 2PL-come want-1sG
'He told (it to) me that you came to look for me.'

Thus in this area too there is a difference between the realisation of the NP in Subject function and the Object function.

In closing, I want to point out a difference in interpretation of experiencer NPs depending on whether the experiencer has a Subject function or an Object function (see Ameka 1990 for the details). The difference is clearly visible when the same verb can occur in the Experiencer as Subject construction as well as the Experiencer as Object construction. Consider these examples:
a. Experiencer as Object
Aha tsri-m
alcohol hate-1sG
lit: 'Alcohol hates me.'
i.e. I am allergic to alcohol
b. Experiencer as Subject
Me-tsri aha
1sG-hate alcohol
'I don't want (to have) alcohol.'

In the Experiencer as Subject Construction, the Experiencer is seen as being volitionally involved in the experiential situation. When the Experiencer is coded as Object it is construed as a non-volitional participant in the situation. This interpretation is also evident in situations where the Experiencer can only have a Subject function in an experiential construction. For instance, emotions viewed as dispositions only allow the Experiencer to occur in the Subject function implying that the Experiencer is involved as a volitional participant. This is the case with the predicate va $\eta u$ 'move body/eye', i.e. be jealous, whose experiencer always has the Subject relation. This shows that the semantic effects of the Subject and Object grammatical relations are also different. 


\section{Conclusion}

In this chapter I have examined the way grammatical relations of the two core arguments of an intransitive, transitive and ditransitive clause are expressed in Ewe. I have argued that in this isolating language, constituent order is the prime indicator of grammatical functions in a clause. I suggested that given the implication that a language that signals grammatical relations by constituent order does not have ergative patterns, Ewe cannot have such patterns. I demonstrated that there is a distinct set of pronouns for the expression of the argument in Subject function and there is another set which is used for the expression of arguments functioning as Direct Object or Second Object or Prepositional Object. It was also shown that nominalisation processes distinguish the grammatical functions: Subject nominalisation employs an alienable genitive strategy while direct Object nominalisation uses the strategy of preposing the NP to the reduplicated verb. The second object always occurs postposed in a nominalisation structure. It has also been shown that the argument having the second object function in a clause behaves differently from the other core relations in using a marker strategy in relativisation and in focus constructions.

In addition, I argued that in serial verb constructions and paratactic biclausal constructions there is an asymmetry in overt realisation between the argument in Subject function and the one in Object function. The most important thing is that the argument in Subject function must be obligatorily expressed in clauses. The argument in Object function is omissible given grammatical and discourse considerations; for instance, if it is coreferential with the NP in object function in the preceding verb phrase or clause. Note that if the NP in Subject function is coreferential with the Subject NP in an earlier clause it still has to be expressed overtly. Furthermore, I pointed out that the obligatoriness of the expression of the Subject argument is reflected in the use of expletive pronouns in modal and complement constructions. Again in this domain as well the expression of the form in Object function is optional, showing Subject and Object asymmetry.

The features that are associated with the Subject and Object functions in Ewe, I have claimed, are linked inextricably to the linguistic type properties of the language. Thus the isolating features of Ewe may explain the importance of constituent order in the definition of grammatical relations and in the obligatoriness of the expression of the argument in Subject function in each clause. One can also employ a linguistic type argument to explain why Ewe 
does not seem to obey the so-called same tense-aspect constraint in serial verb constructions. It could be attributed to the fact that Ewe is not a grammatical tense language. Moreover, the requirement in Ewe that certain verbs must obligatorily have their complements expressed means that object sharing may not always hold in a serial verb construction. Such understandings are necessary for a holistic characterisation of grammatical relations in serialising languages. What I am asserting is that we can understand the grammatical relations in a language better if attention is paid to the linguistic type properties of the language.

\section{Notes}

* I am grateful to Bill McGregor who, as they say in Australia, dobbed me in to write this chapter. He also made available to me his chapter on Warrwa from which I greatly benefited. For discussions of some of the issues raised here, and for comments on earlier drafts, I am grateful to James Essegbey and Eva Schultze-Berndt. To the editors, I say thank you for everything, but above all, for your tolerance.

1. To determine the pattern of a language, recourse has been made to the so-called syntactic-semantic primitives of A (=transitive subject) S (=intransitive subject) and $\mathrm{O}$ (=transitive object) proposed by Dixon (e.g. 1994) among others. Roughly speaking, a pattern is ergative if it treats A distinct from the way it treats the $S$ and the O. A nominative-accusative pattern treats the $\mathrm{A}$ and $\mathrm{S}$ in the same way and treats $\mathrm{O}$ differently. The use of these primitives and the problems inherent with them have been pointed out in recent times by many people (see e.g. McGregor this volume; Wierzbicka 1998; Harris 1997; Durie 1988; Mithun and Chafe 1999, among others).

2. There are two nyá modals in Ewe: one for marking epistemic certainty and the other for the complex function of expressing dynamic modality, that is, 'ability and disposition'. The latter form is what is involved in the construction being discussed here (see Ameka (1991) for a comparison of the two forms and the constructions in which they are involved).

3. The categorial status of these forms is debatable. The position adopted here reflects their functional behaviour in serial verb constructions as connectives. They could also be analysed as modals from a distributional point of view.

High tones are marked throughout with an acute accent in addition to the low tones that are customarily marked in the traditional orthography with a grave accent. The hacek marks a rising tone. Ewe orthographic $f$ and $v$ are the voiceless and voiced bilabial fricatives respectively. Note that in italics the distinction between the bilabial $f$ and the labio-dental $f$ is unfortunately lost.

Where examples are taken from texts there is an indication of the source either by the author date and page system (e.g. Kwamuar 1997:15) or by title and text line number in the database (e.g. Agbezuge 2312). 


\section{References}

Aikhenvald, A.Y. 1999. Serial constructions and verb compounding. Evidence from Tariana (North Arawak). Studies in Language 23(3), 469-98.

AmeKa, F.K. 1990. The grammatical packaging of experiencers in Ewe: a study in the semantics of syntax. Australian Journal of Linguistics 10(2), 139-81.

AмекA, F. K. 1991. Ewe: its grammatical constructions and illocutionary devices. PhD thesis. Canberra: Australian National University.

Ameka, F. K. 1992. Focus constructions in Ewe and Akan: a comparative perspective. In Proceedings of the Kwa Comparative Syntax Workshop MIT 1992 (= MIT Working Papers in Linguistics 17), C. Collins and V. Manfredi (eds.) 1-25. Cambridge MA: MIT Dept of Linguistics and Philosophy.

Ameka, F. K. 1994. Transitivity and object typology in Ewe. Workshop on Object positions in Benue-Kwa, Leiden University, June 1-3, 1994.

AмeкA, F. K. 1995. The linguistic construction of space in Ewe. Cognitive Linguistics 6(2/3), 139-80.

AмeкA, F.K. 1996. Body parts in Ewe grammar. In The grammar of inalienability: a typological perspective on body part terms and the part-whole relation, $\mathrm{H}$. Chappell and W. McGregor (eds.), 783-840. Berlin: Mouton.

Ameka, F. K. Forthcoming. Syntax and pragmatics mismatches: on argument focusing in Ewe. To appear in Proceedings of the 9th Niger Congo Syntax and Semantics Workshop, Legon: University of Ghana.

Andrews, A.D. 1985. The major functions of the noun phrase. In Language typology and syntactic description. Vol. 1, T.A. Shopen (ed.), 62-54. Cambridge: Cambridge University Press.

BAKER, M. 1989. Object sharing and projection in serial verb constructions. Linguistic Inquiry 20(4), 513-53.

Campbell, R. 1996. Serial verbs and shared arguments. The Linguistic Review 13, 83-118.

Clements, G. N. 1972. The verbal syntax of Ewe. PhD thesis. London: University of London.

Clements, G.N. 1975 [1979]. The logophoric pronoun in Ewe: its role in discourse. Journal of West African Languages 10(2), 141-77.

Collins, C. 1993. Topics in Ewe syntax. PhD dissertation. Cambridge MA: Massachusetts Institute of Technology.

Collins, C. 1997. Argument sharing in serial verb constructions. Linguistic Inquiry 28(3), 461-97.

Crowley, T. 1999. What are serial verbs? A Colloquium paper. Nijmegen: Max Planck Institute for Psycholinguistics.

Davidse, K. 1997. The Subject-Object versus the Agent-Patient asymmetry. Leuvense Bijdragen - Leuven contributions in linguistics and philology 86(4), 413-31.

Dechaine, R.-M. 1993. Serial verb constructions. In Syntax: An International Handbook of Contemporary Research, J. Jacobs (ed.), 789-825. Berlin: Walter de Gruyter.

DeLancey, S. 1995. Verbal case frames in English and Tibetan. http://darkwing.uoregon. edu/ delancey/papers/caseframes.html. 
DeLancey, S. 1997. What an innatist argument should look like. In SKY 1997 (1997 Yearbook of the Linguistics Association of Finland), T. Hankoja, M.-L. Helasuvo and M. Miestamo (eds.), 7-24. Helsinki: Linguistics Association of Finland.

Dixon, R.M.W. 1994. Ergativity. Cambridge: Cambridge University Press.

Dryer, M.S. 1997. Are grammatical relations universal? In Essays on language function and language type: Dedicated to T. Givón, J. Bybee, J. Haiman S. A. Thompson (eds.), 115-44. Amsterdam: John Benjamins.

Durie, M. 1988. Preferred argument structure in an active language: arguments against the category "intransitive subject". Lingua 74, 1-25.

Durie, M. 1997. Grammatical structures in verb serialisation. In Complex predicates, A. Alsina, J. Bresnan and P. Sells (eds.), 289-354. Stanford: CSLI.

Duthie, A.S. 1996. Introducing Ewe linguistic patterns. Accra: Ghana Universities Press.

Dzameshie, A. K. 1983. Relative clause formation in Ewe. MA thesis. Indiana University.

EssegBey, J. 1999. Inherent complement verbs revisited: towards an understanding of argument structure in Ewe. PhD dissertation. Leiden University.

Essegbey, J. 2001. The syntax of inherent complement verbs in Ewe. In New directions in Ghanaian linguistics, F. K. Ameka and E.K. Osam (eds.). Accra: ACP Publishers.

Essegbey, J. Forthcoming. The Potential in Ewe: a reexamination of the so-called -a-future marker. To appear in Aspect and modality in Kwa languages of Ghana, F. K. Ameka and M.E.K. Dakubu (eds.)

FILlmore, C. 1970. The grammar of hitting and breaking. In Readings in English transformational grammar. R. Jacobs and P. Rosenbaum (eds.), 120-33. Waltham, MA: Ginn.

Foley, W.A., and VAN VAlin, R. D. 1984. Functional syntax and universal grammar. Cambridge: Cambridge University Press.

Givón, T. 1997. Grammatical relations: an introduction. In Grammatical relations: $a$ functionalist perspective, T. Givón (ed.), 1-84. Amsterdam: John Benjamins.

Goldberg, A. 1995. Constructions: A Construction Grammar approach to argument structure. Chicago: The University of Chicago Press.

Harris, A. 1997. Review of Dixon (1994) Ergativity. Language 73, 359-74.

Keenan, E. 1976. Towards a universal definition of 'Subject'. In Subject and Topic, C. Li (ed.), 303-33. New York: Academic Press.

Kwamuar, S. 1997. Ewo moya na Togbi Agokəli [It surprised Chief Agokoli]. Accra: Bureau of Ghana Languages.

Levin, B., and Rapapport Hovav, M. 1995. Unaccusativity. Cambridge, Mass: MIT Press.

LEwIS, M. 1999. From switch reference to recessive subject marking: Third person subject pronoun patterns in Gen, Ewe and Fon. 30th Annual Conference on African Linguistics, University of Illinois, Urbana-Champaign, 1999.

LEwIS, M.n.d. Ewe relativization, NP accessibility and universal grammar. Department of Linguistics, Indiana University.

LorD, C. 1993. Historical change in serial verb constructions. Amsterdam: John Benjamins.

Mithun, M. and Chafe, W. 1999. What are S, A, and O ? Studies in Language 23(3), 569-96.

McGregor, W. this volume. Ergative and accusative patterning in Warrwa. 
Obianim, S. J. 1990. Agbezuge. Accra: Sedco.

Osam, E. K. 1996. The object relation in Akan. Afrika und Übersee 79, 57-83.

Osam, E.K. 1997. Serial verbs and grammatical relations in Akan. In Grammatical relations: a functionalist perspective. T. Givón (ed.), 253-79. Amsterdam: John Benjamins.

Palmer, F.R. 1994. Grammatical roles and relations. Cambridge: Cambridge University Press.

SAAH, K. K. 1992. Null object constructions in Akan. In Proceedings of the Kwa comparative syntax workshop (= MIT Working Papers in Linguistics 17). C. Collins and V. Manfredi (eds.), 219-44. Cambridge, Mass: MIT Department of Linguistics and Philosophy.

Schachter, P. 1974. Non-transformational acount of serial verbs. Studies in African Linguistics, Supplement 5, 253-70.

Stewart, O.T. 1998. The serial verb construction parameter. Ph. D thesis. McGill University.

Van Valin Jr., R.D., and LaPolla, R. J. 1997. Syntax: Structure, meaning and function. Cambridge: Cambridge University Press.

Westermann, D. 1930. A study of the Ewe language. Oxford: Oxford University Press.

Wierzbicka, A. 1998. Anchoring linguistic typology in universal semantic primes. Linguistic Typology 2(2), 141-94. 